\title{
The Effect of Distributed Generator Injection with Different Numbers of Units on Power Quality in the Electric Power System
}

\author{
Robi Kurniawan $^{\bowtie 1}$, Ardiansyah Nasution², Arnawan Hasibuan ${ }^{2,7}$, Muzamir Isa $^{3}$, Muskan Gard4, Shrikant Vasantrao \\ Bhunte5,6, \\ ${ }^{1}$ Renewable Energy Engineering Master's Program, Malikussaleh University, Bukit Indah, Lhokseumawe, 24351, Indonesia \\ ${ }^{2}$ Department of Electrical Engineering, Malikussaleh University, Bukit Indah, Lhokseumawe, 24351, Indonesia \\ ${ }^{3}$ Universiti Malaysia Perlis, Perlis, Malaysia \\ ${ }^{4}$ Amity University Rajasthan, India \\ ${ }^{5}$ Dr. Sau. Kamaltai Gawai Institute of Engineering and Technology, Darapur, Dist. Amravati, Maharashtra, India, 444814 \\ ${ }^{6}$ Sant Gadge Baba Amravati University, Amravati, Maharashtra, India, 444702 \\ ${ }^{7}$ School of Electrical System Engineering, University of Malaysia Perlis, Perlis, Malaysia \\ robikurniawan467@gmail.com; ardiansyah.elekrounimal@gmail.com; arnawan@unimal.ac.id; muzamir@unimap.edu.my; \\ mgarg@jpr.amity.edu; shrikant_bhunte@rediffmail.com; \\ ${ }^{\circledR}$ Corresponding Author: robikurniawan467@gmail.com | Phone: +6282277453022
}

Received: September 8, 2021

Revision: September 18, 2021

Accepted: September 30, 2021

\begin{abstract}
Distributed Generation (DG) is a small capacity generator located in the electricity distribution system and is usually placed on buses that are connected directly to the load. Placement of distributed generation is one of the technical efforts to reduce voltage drop and power losses in the system. In addition, load flow analysis is a study to plan and determine the amount of power in an electric power system. The results of power losses after adding distributed generation were the best in the fifth experiment on bus 149, where the system experienced a total loss of active power (P) previously of $720,822 \mathrm{~kW}$, to $682,939 \mathrm{~kW}$ and total loss of reactive power (Q) previously of $530.02 \mathrm{kVar}$, to 405.835 kVar. From the results of the calculation of the power flow using ETAP software (Electrical Transient Analyzer Program). So, it can be concluded that the electrical network system can be said to be good. The results obtained are the more DG (wind turbine generator) that is input into the bus it will reduce the voltage drop that occurs. After simulating the overall voltage drop, it still meets the standards according to the results of the Text Report on ETAP.

Keywords: distributed generator; load flow; power loss analysis; ETAP
\end{abstract}

\section{Introduction}

Energy problems have a tendency to increase and develop, including in developing countries. Some countries are endowed with energy resources that will only run out after a few more decades. In addition, technological developments regarding renewable energy sources combined with the growing public attention to environmental issues, Distributed Generation (DG) connected to the network has been widely used (Distribusi, 2012).In recent years, the utilization of abundant energy resources and environmentally friendly operations have been very popular in distribution system research. Distributed generators are developed in developed countries to support the country's electricity needs. Distributed generators are generators with small capacities and are widely introduced in today's power distribution systems(Luthfi et al., 2013)(Musaruddin et al., 2017). Distributed generators are considered as the right solution to overcome the shortage of energy supply and overcome problems in the electric power distribution system such as power loss, system balance, and also overcome critical loads that experience voltage drops. The installation of distributed generating units is usually connected to the customer side of the distribution system(Bawan, 2012)(Artawa et al., 2017).

Before installing DG, it is necessary to study and analyze the impact of DG placement for different buses, this is done to determine the best location for DG installation. DG placement can be done at substations, distribution networks and can also be installed on buses that directly supply the load (T. Elektro, 2012)(. et al., 2014). The international standards used as references are the standards of the Institute of Electrical and Electronics Engineers (IEEE) and the International Electrotechnical Commission (IEC). The value of voltage, frequency and maximum load are important parameters in the distribution system. The standard voltage is $\pm 5 \%$ of the nominal voltage, while the standard frequency is $\pm 2.5 \%$ of the natural frequency (Permana, 2016). 


\section{Literature Review \\ Distributed Generation (DG)}

Distributed Generation is defined as power generation on the distribution network or on the customer side of the network.Distributed Generation (DG) serves as a supply to consumers located far from the central power supply system through small-scale power plants. In addition, DG can also increase the reliability of power supplied to customers, reducing losses in transmission and distribution systems(Thong et al., 2005). The maximum rating of DG that can be connected to the distribution network depends on the capacity of the distribution network, which is correlated with the level of distributed generation. Usually units rated up to 3-5 MW are most often connected to the internal power supply network of consumers, and those above - to the external power supply system (Guseynov \& Akhundov, n.d.).

Table 1. DG capacity and rating data

\begin{tabular}{cc}
\hline Capacity DG & Installed Power (MW) \\
\hline Micro & 1 Watt $<5 \mathrm{~kW}$ \\
Small & $5 \mathrm{~kW}<5 \mathrm{MW}$ \\
Intermediate & $5 \mathrm{MW}<50 \mathrm{MW}$ \\
Big & $50<300 \mathrm{MW}$ \\
\hline
\end{tabular}

Power flow analysis in an electric power system is an analysis that reveals the performance of an electric power system and the flow of power (real and reactive) for certain conditions when the system is working. The main result of the power flow is the magnitude and phase angle of the voltage on each line (bus), the real power and reactive power present in each line. The results of the power flow analysis can be used to determine the amount of losses (power and voltage losses), reactive power allocation and the ability of the system to meet load growth(J. T. Elektro et al., 2015).The main purpose of the study of the electric power system is to determine the magnitude of the voltage, the angle/vector of the voltage, the flow of active and reactive power in the line, and the power losses that occur in an electric power system. So on each bus there are four quantities, namely P, Q, and V. In the study of power flow, two of the four quantities are known and the other two need to be found. Based on this, buses are divided into three types, namely load buses, generator buses (gen buses), and swing buses (slack buses)(Timur et al., 2018).

Based on SPLN No.72 of 1987, the value of the power loss is required to determine the reliability of the system, namely the value of power loss and voltage drop should not exceed the allowable standard of $5 \%$ for voltage loss and $10 \%$ for power loss. If it exceeds the allowable standard, it will cause losses for consumers and electricity suppliers(Albaroka et al., 1987).Power loss formula:

$$
\begin{aligned}
& \Delta P=I^{2} R \frac{L^{3}}{3} \\
& \Delta Q=I^{2} x \frac{L^{3}}{3}
\end{aligned}
$$

Information $: \mathrm{P}=$ Active Power (Watts)

$\mathrm{Q}=$ Reactive Power $(\mathrm{VAR})$

Voltage drop in general is the voltage applied to the load. The voltage drop $\mathrm{V}$ in the conductor is greater if the current I in the conductor is greater and if the resistance of the conductor RL is also greater. The stress can be calculated using the relationship approach formula as follows:

$$
(\Delta V)=\sqrt{3} I L(R \cdot \cos \varphi+X \cdot \sin \varphi)
$$

\section{Results and Discussion}

\section{Description of Research Results}

From the data generated at the Titi Kuning PLTD, it can be simulated using the Etap 12.6 software, which consists of 1 Generator, 6 Power Grids, 40 Loads, 120 Branches, 122 Buses. Below is an image generated from the Etap software.

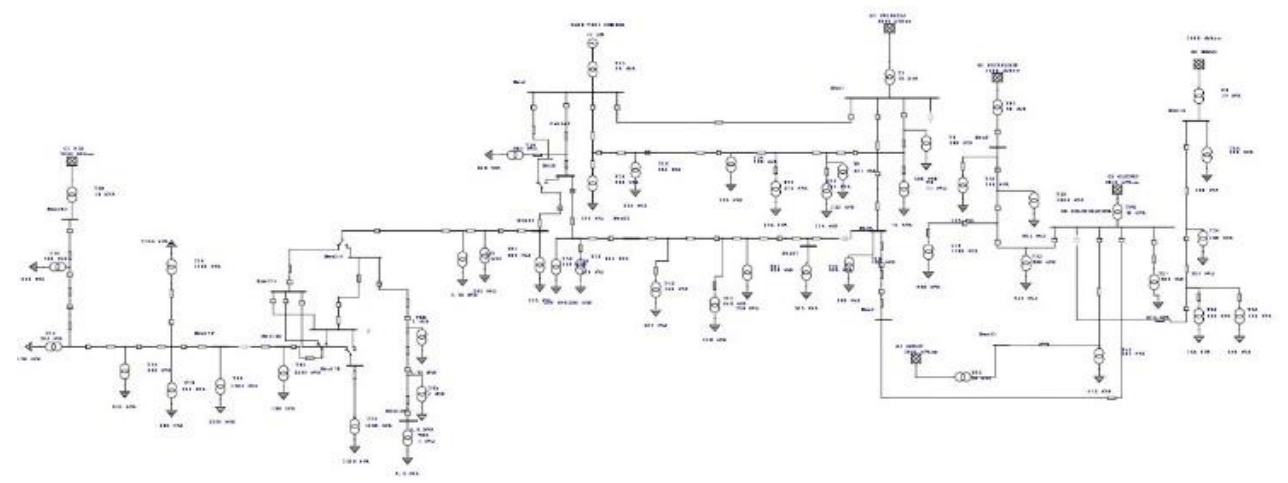

Figure 1. Single Line Diagram of PLTD Titi Kuning 
The picture above is a single line diagram before the DG injection was spread, where on the PLTD titi kuning line to the GI KIM there were several buses that experienced disturbances.

\section{Injectable DG Capacity}

Distributed Generation (DG) which will be injected in this experiment is a wind turbine generator with an assumed capacity according to the wind shear profile around the area. With the initial data obtained the average wind speed of $2.3 \mathrm{~m} / \mathrm{s}$ with a height of $10 \mathrm{~m}$. Then developed with the following formula.

$$
V=V_{\text {ref }} I_{n}\left(\frac{Z}{z_{o}}\right) / I_{n}\left(\frac{Z_{r e f}}{Z_{o}}\right)
$$

By using the assumption of roughnes length of 0.03 . Then the results obtained in the table as follows.

Table 2. Wind Shear Profil

\begin{tabular}{cc}
\hline Height $(\mathrm{m})$ & Wind speed above ground level $(\mathrm{m} / \mathrm{s})$ \\
\hline 1 & 0.789702 \\
40 & 2.754645 \\
60 & 3.20929 \\
80 & 3.47524 \\
100 & 3.663935 \\
120 & 3.810298 \\
140 & 3.929885 \\
160 & 4.030994 \\
180 & 4.118579 \\
200 & 4.195835 \\
240 & 4.264942 \\
260 & 4.327458 \\
280 & 4.38453 \\
300 & 4.437031 \\
\hline
\end{tabular}

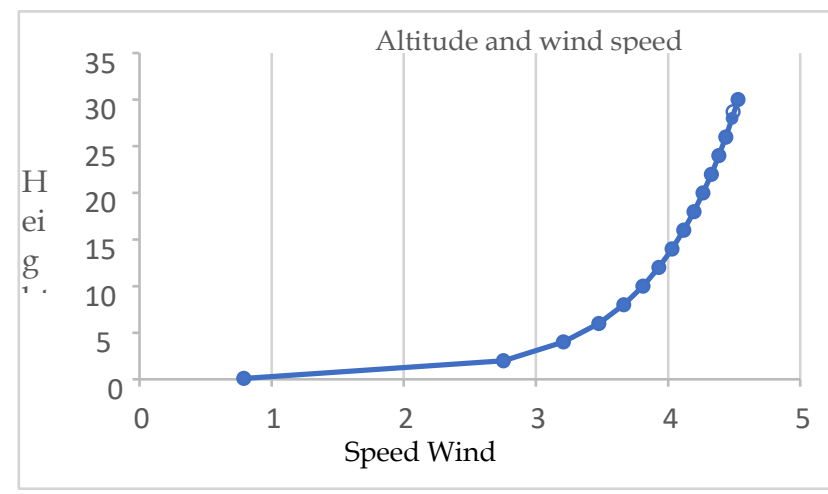

Figure 2. Chart Wind Shear Profil

From the graph above, it can be assumed that the turbine height that can be used is $120 \mathrm{~m}$ with a turbine radius of 40. Then the power generated can be calculated according to the following formula.

$$
\mathrm{P}=\frac{1}{2} \rho \cdot \mathrm{A} \cdot v^{3}
$$

It is assumed that the power that can be generated by the turbine is $84 \mathrm{~kW}$. Then it will be injected with the amount of 10 in the ETAP software.

\section{Load Flow Analysis And Voltage Drop}

Power network analysis is a process of observing several electrical quantities such as bus voltage profiles, real power flow, and reactive power on lines in the electric power system, while voltage drop is the amount of voltage lost on the line/conductor. The simulation results of the power flow values and power losses on the bus before the DG injection is carried out can be seen in the following table. 
Table 3. Power Flow and Voltage Drop Analysis

\begin{tabular}{ccc}
\hline Bus ID & Nominal $(\mathrm{kV})$ & Voltage $(\%)$ \\
\hline Bus1 & 150 & 100 \\
Bus2 & 20 & 103,28 \\
Bus4 & 21 & 101,06 \\
Bus5 & 20 & 102,6 \\
Bus6 & 21 & 100,62 \\
Bus8 & 20 & 102,52 \\
Bus9 & 20 & 102,49 \\
Bus11 & 20 & 102,53 \\
Bus12 & 150 & 100 \\
Bus13 & 20 & 99,82 \\
Bus59 & 6 & 100 \\
Bus89 & 21 & 98,3 \\
Bus92 & 21 & 100,45 \\
Bus97 & 21 & 100,26 \\
Bus139 & 21 & 89,68 \\
Bus144 & 21 & 92,1 \\
Bus 145 & 21 & 93,01 \\
Bus148 & 21 & 93 \\
Bus149 & 21 & 89,79 \\
Bus154 & 20 & 102,06 \\
Bus155 & 150 & 100 \\
Bus174 & 21 & 93,01 \\
Bus178 & 21 & 93,01 \\
Bus182 & 150 & 100 \\
Bus184 & 150 & 100 \\
Bus185 & 150 & 100 \\
GH & 20 & 102,49 \\
\hline Doksanggul & & \\
\hline
\end{tabular}

Information : $\square=$ Critical limit (\%) Marginal limit (\%)

The table in red is the bus that experienced a voltage drop of $>5 \%$ before the DG injection was spread, namely bus 139 , bus 144 , bus 145 , bus 148 , bus 149 , bus 174 , bus 178 . Where is the maximum voltage drop limit generated on the bus. by $5 \%$. So that the voltage drop generated by the bus above has exceeded the applicable IEE 141 standard. Then a simulation of DG injection will be carried out on several buses that experience the highest voltage drop. So that it can be produced with power losses reaching $891.3 \mathrm{~kW}$.

1. Distributed Generation (DG) is installed on the 139 bus

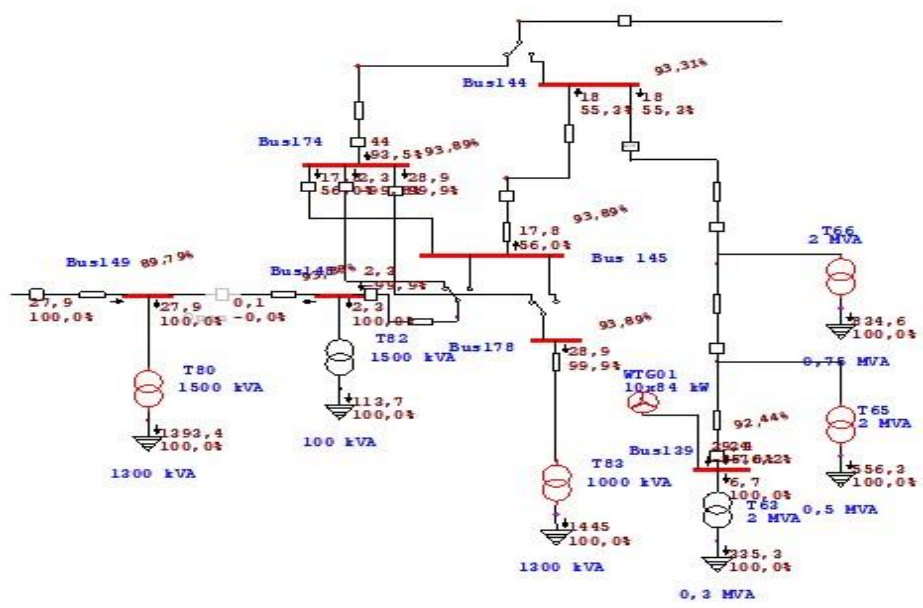

Figure 3. DG mount on 139 bus

From the simulation results after DG injection on bus 139 , the voltage drop that was previously $89.62 \%$ becomes $92.44 \%$. So that the voltage drop increases by $3.18 \%$ from before, so that after the DG wind turbine generator is inserted or added to bus 139 it can affect the voltage value on other buses.

2. Distributed Generation (DG) is installed on the 144 bus 


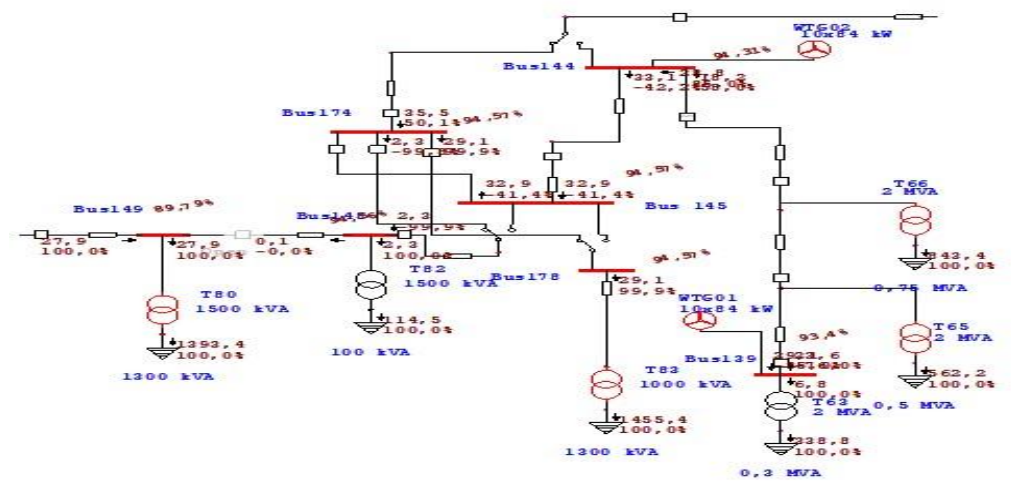

Figure 4. DG mount on 144 bus

From the simulation results after the DG injection is spread, the resulting value for the previous voltage drop is $92.1 \%$ to $94.31 \%$. The voltage drop increased by $2.21 \%$ from before.In addition, after the scattered DG injection was carried out, the previously injected bus on bus 139 also experienced a voltage drop change of $1 \%$.

3. Distributed Generation (DG) is installed on the 145 bus

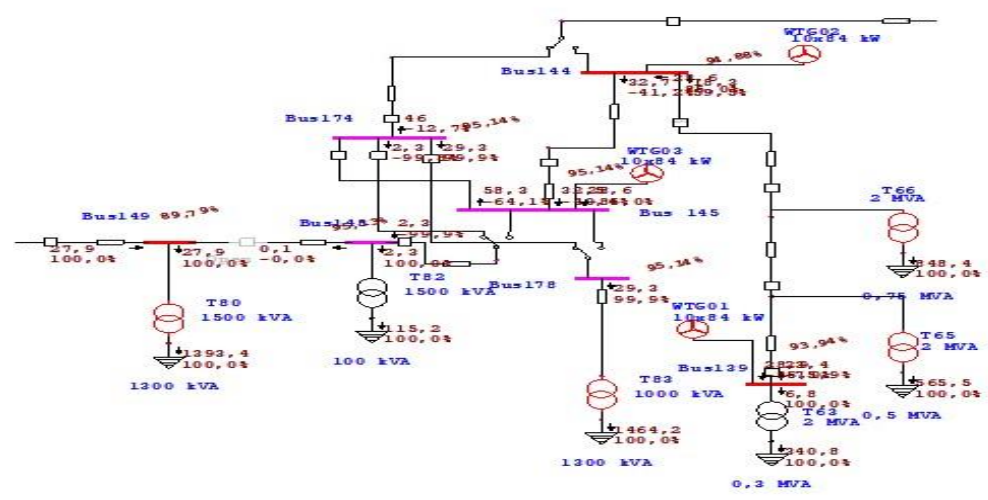

Figure 5. DG mount on 145 bus

From the simulation results of DG injection spread on bus 145, the power factor increased where previously it was 93.01\% and after DG injection it became $95.14 \%$, and after the DG injection there were several buses whose power factor increased or affected bus 139, and bus 144 .

4. Distributed Generation (DG) is installed on the 149 bus

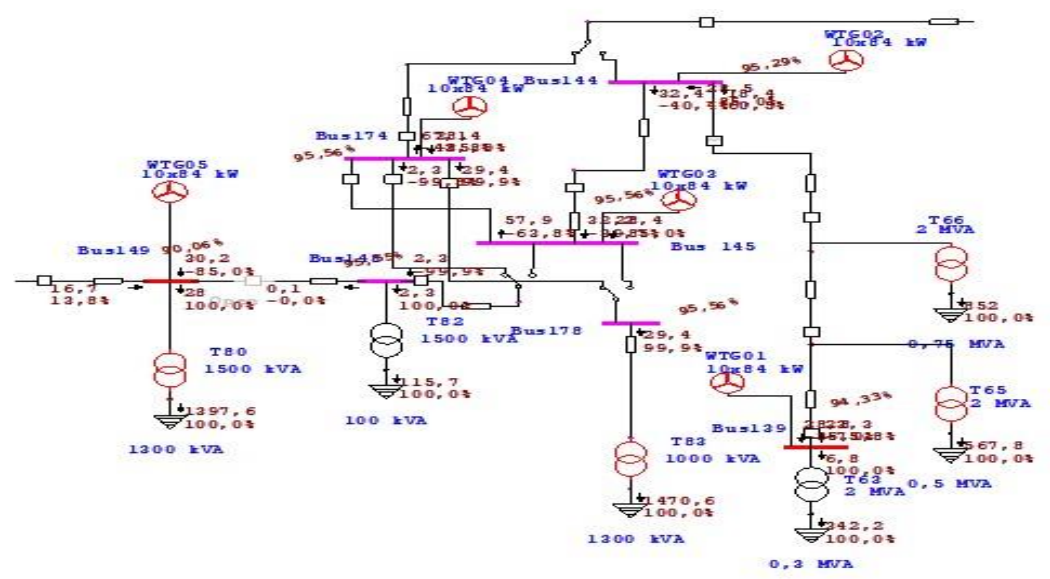

Figure 6. DG mount on 149 bus

From the simulation results after DG injection, there are several buses whose power factor increases, namely bus 139 , bus 144 , bus 145 , bus 178 , bus 174 . The increase in power factor occurs because the DG supplies active power (P) to the bus point that has been injected. from $89.79 \%$ to $90.06 \%$. Bus 139 from $89.62 \%$ to $94.33 \%$, bus 144 from $92.1 \%$ to $95.29 \%$, bus 145 from $93.01 \%$ to $95.14 \%$, bus 178 from $93.01 \%$ to $95.56 \%$.

5. Distributed Generation (DG) is installed on the 174 bus 


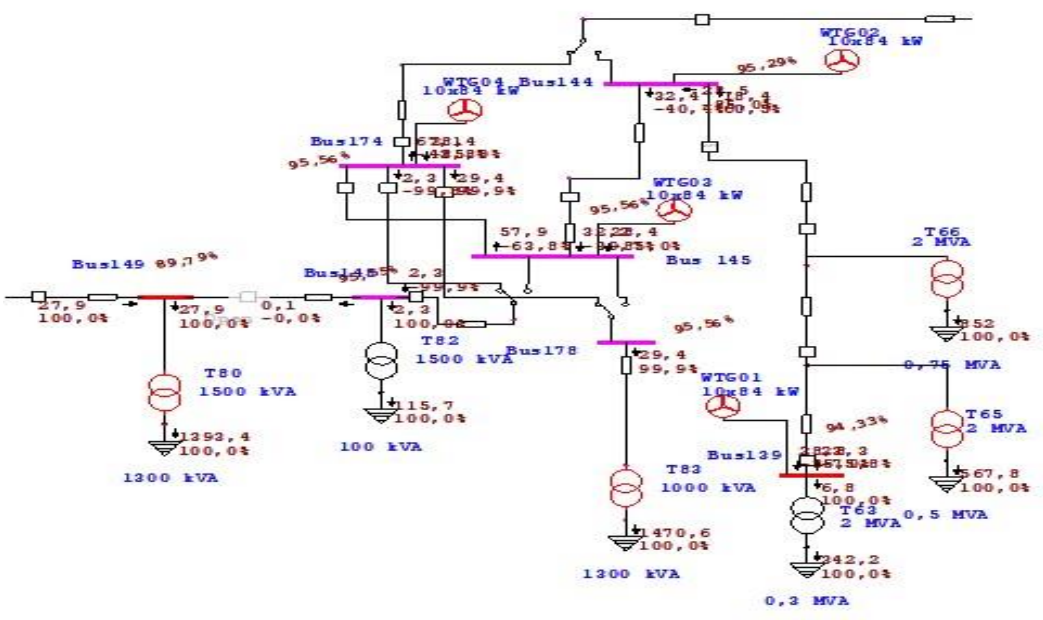

Figure 7. DG mount on 174 bus

From the simulation results after DG injection on bus 174 there are several buses whose power factor increased, namely bus 139 , bus 144 , bus 145 , and bus 178 . Where the power factor increased significantly from $93.01 \%$ to $95.56 \%$, bus 139 from $89.62 \%$ to $94.33 \%$, bus 144 from $92.1 \%$ to $95.29 \%$, bus 145 from $93.01 \%$ to $95.14 \%$, and bus 178 from $93.01 \%$ to $95.56 \%$.

After installing the DG wind turbine generator on the network, it can help meet the increasing power needs in the distribution network, although the use of the DG wind turbine generator only reduces the voltage drop that occurs by 2 $3 \%$.

\section{The impact of DG injection is spread}

After being injected with DG and simulated in the form of ETAP 12.6 software, at the point of the bus experiencing a voltage drop, the results of the power flow are shown below:

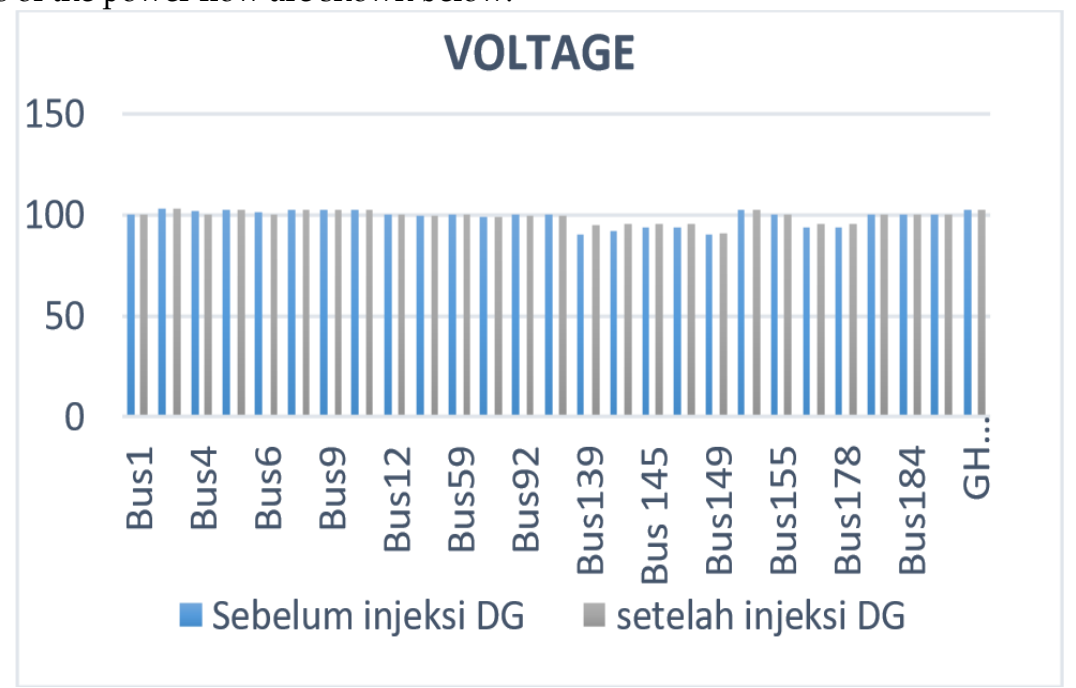

Figure 8. DG Injection Chart Before And After

From the graphic above, the scattered DG injection that is carried out can affect the power flow in the network, where after the installation of the DG wind turbine generator is carried out to each specified bus whose voltage drop exceeds the IEE standard by $5 \%$ and the value specified yield of $4 \%$ even though there are two buses that are still experiencing voltage drops, namely, bus 139 and bus 149, where the power factor supplied from the addition of the DG wind turbine generator is still lacking, so it does not reach the $95 \%$ standard. 


\section{Power Loss in the Electric Distribution System}

\section{Power Loss}

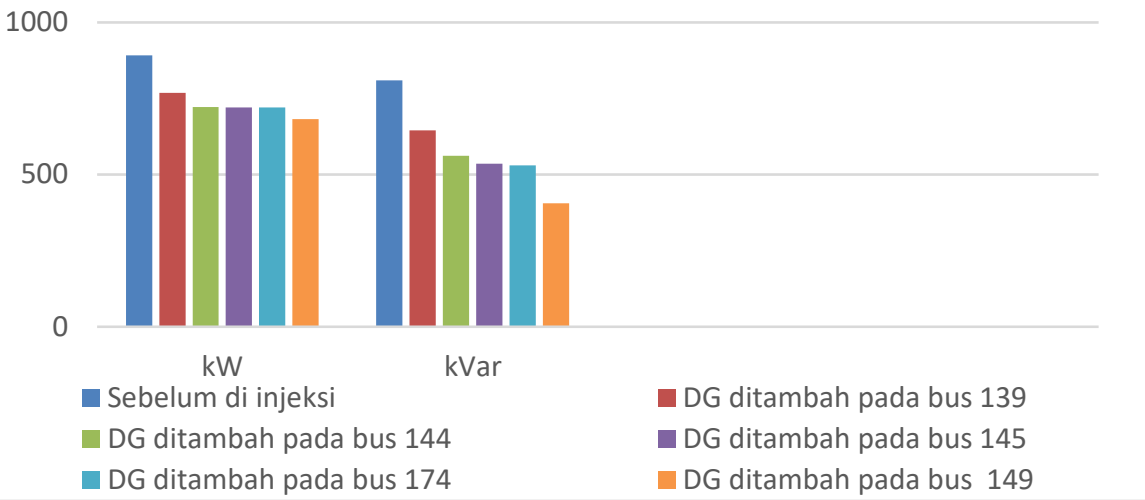

Figure 9. Graph of Losses After Distributed DG Injection

This graph shows the difference in the value of power losses, before DG injection is done, DG is added to bus 139, bus 144 , bus 145 , bus 174, bus 149 . The more DG is added, the smaller the losses that occur when the power is active. (P) and reactive power $(\mathrm{Q})$.

Table 4. Comparison of Total Power Loss

\begin{tabular}{ccc}
\hline DG Injection on Bus & Total active power losses $(\mathrm{kW})$ & Total reactive power losses (kVar) \\
\hline Without DG & 891.3 & 809.5 \\
Bus 139 & 768.3 & 644.7 \\
Bus 144 & 721.3 & 561.6 \\
Bus145 & 721.2 & 536.1 \\
Bus149 & 720.8 & 530.02 \\
Bus 179 & 682.9 & 405.8 \\
\hline
\end{tabular}

\section{Conclusions}

From the results of the analysis and discussion carried out, the following conclusions can be drawn:

1. The impact of scattered generator injection is to increase the voltage profile on all buses and reduce power losses that occur in the feeder by 2 to $3 \%$.

2. The best results on the DG (wind turbine generator) injection were carried out in the 5th experiment on bus 149 , where some buses experienced a voltage drop below the IEEE standard of $\pm 5 \%$, after being injected with Distributed Generation the value on the bus rose.

3. The overall power losses before and after DG injection are the active power (P) previously $891.3 \mathrm{~kW}$, to $682.9 \mathrm{~kW}$, reactive power $(\mathrm{Q})$ previously $809.5 \mathrm{kVar}$, to $405.8 \mathrm{kVar}$.

\section{References}

S., Yunus, S., \& . A. (2014). Analisa Pengaruh Integrasi Pembangkit Tersebar dalam Sistem Komposit. Jurnal Nasional Teknik Elektro, 3(1), 95. https://doi.org/10.25077/jnte.v3n1.61.2014

Albaroka, G., Elektro, T., Surabaya, U. N., Elektro, T., \& Surabaya, U. N. (1987). analysis power loss on the distribution network of the barat jaya in the surabaya selatan using software ETAP 12.6. 72.

Artawa, I. N. C., Sukerayasa, I. W., \& Dwi Giriantari, I. A. (2017). Analisa Pengaruh Pemasangan Distributed Generation Terhadap Profil Tegangan Pada Penyulang Abang Karangasem. Majalah Ilmiah Teknologi Elektro, 16(3), 79. https://doi.org/10.24843/mite.2017.v16i03p13

Bawan, E. K. (2012). Dampak Pemasangan Distributed Generation Terhadap Rugi-Rugi Daya. Jurnal Ilmiah Foritek, 2(21), 216-223.

Distribusi, J. (2012). Analisys placement of distributed generation. 1(1).

Elektro, J. T., Teknik, F., Semarang, U. N., \& Fibers, P. (2015). Analysis of the powe flow of the electrical power system in the Texturizing Section of PT Asia Pacific Fibers tbk Kendal using ETAP Power station 4.0 software. Jurnal Teknik Elektro, 7(1), 7-10.

Elektro, T. (2012). Effect Of Distributed Generation Installation On The Effect Of Applying Distributed Generation To Voltage. 13(1), 12-19.

Guseynov, A. M., \& Akhundov, B. S. (n.d.). Defining Impact of Distributed Generation on Power System Stability. 122-125.

Luthfi, N. I., Yuningtyastuti, \& Handoko, S. (2013). Optimasi Penempatan Distributed Generation Pada Ieee 30 Bus System Menggunakan Bee Colony Algorithm Metode. Transient, 2(3), 758-763.

Musaruddin, M., Munawir, A., \& Hay, S. (2017). Pengaruh Pemasangan Pembangkit Terdistribusi ( Distributed Generation ) Terhadap Magnitude Arus Gangguan pada Sistem Distribusi Tenaga Listrik. 2(2502).

Permana, S. F. (2016). Analisis Pengaruh Pemasangan Distributed Generation Pada Jaringan Distribusi Pusdiklat Migas Cepu. 
Thong, V. Van, Driesen, J., \& Belmans, R. (2005). Interconnection of Distributed Generators and Their Influences on Power System. 6(1), 127-140.

Timur, K., Software, M., Aribowo, B. T., \& Muksim, M. (2018). simulation and load flow analysis of interconection system. September, 626-633. 